\section{СУБЭТНИЧЕСКИЕ ДИФФЕРЕНЦИАЦИИ РОССИЙСКИХ ЭТНОСОВ (НА ПРИМЕРЕ КАЛМЫКОВ И ТУВИНЦЕВ)"}

\author{
Чимиза К. Ламажаа \\ Московский гуманитарный университет, \\ Российская Федерация,
} Людмила В. Намруева Калмыцкий научный центр Российской академии наук, Российская Федерация

В статье предлагается рассматривать тему разделительных, различительных явлений и процессов в этносоциальной жизни российских регионов, которые имеют в своей основе сложносоставной характер коренного населения. Этот ряд явлений и процессов авторы предлагают называть субэтническими дифференциациями, различая их декларируемые формы и недекларируемые. В качестве мате-
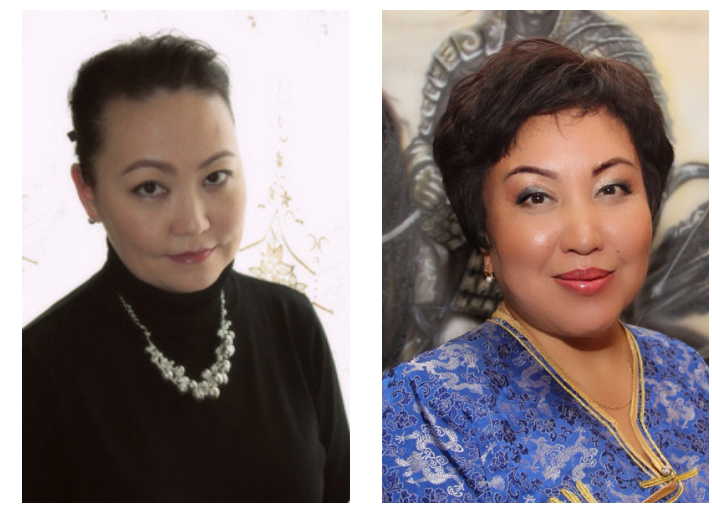

The article examines the issue of the differential processes and events in the ethnosocial lives of Russia's regions. These processes and events, stemming from the complexity of indigenous populations, can be termed 'subethnic differentations', which, in their turn, can appear in declarative or non-declarative forms.

"Статья подготовлена в том числе в рамках Госзадания № 12.885.2018/12.3 «Мониторинг этноконфессиональной ситуации в полиэтничных регионах Российской Федерации (Ростовская область, Астраханская область, Республика Калмыкия)» / The article has been prepared within the scope of the State Commission No. 12.885.2018/12.3 "Monitoring the ethnoreligious situation in multiethnic regions of the Russian Federation (Rostov Oblast, Astrakhan Oblast, Republic of Kalmykia)".

Ламажаа Чимиза Кудер-ооловна - доктор философских наук, заместитель директора по научной работе Института фундаментальных и прикладных исследований Московского гуманитарного университета. Адрес: 111395, Россия, г. Москва, ул. Юности, д. 5, корп. 6. Тел.: +7 (499) 374-73-90. Эл. адрес: lamajaa@tuva.asia

Намруева Людмила Васильевна - кандидат социологических наук, руководитель отдела социально-политических и экологических исследований Калмыцкого научного центра Российской академии наук. Адрес: 358000, Россия, г. Элиста, ул. Илишкина, д. 8. Тел.: +7 (961) 547-58-40. Эл. адрес: lnamrueva@ yandex.ru

Lamazhaa Chimiza Kuder-oolovna, Doctor of Philosophy, Deputy Director, Institute of Fundamental and Applied Studies, Moscow University for the Humanities. Postal address: Bldg. 6, 5 Yunosti St., 111395 Moscow, Russian Federation. Tel.: +7 (499) 374-73-90.E-mail: lamajaa@tuva.asia

Namrueva Lyudmila Vasilyevna, Candidate of Sociology, associate Professor, Head of Department of sociopolitical and ecological researches, Kalmyk Institute for Humanities of the Russian Academy of Sciences. Postal address: 8 Ilishkina, 358000, Elista, Russia. Tel.: +7 (961) 547-58-40. E-mail: lnamrueva@yandex.ru 
риала для анализа авторы рассматривают субэтнические дифференциации современных калмыков и тувинцев.

Экскурс в этногенез калмыков и тувинцев показывает сложную структуру данных этносов. Основой социальной структуры общества калмыков и тувинцев был род, который считался по отцзовской линии. Вся родня по отцјовской линии составляла одно поселение (хотон, аал). Родовым связям, родовой идентификации, знанию своего рода придавалось огромное значение. Тем не менее, внутренняя структура этноса была сложнее и включала не только роды, особенно у калмыков. Исторические события $X X$ в. по-разному повлияли на этносоциальные процессы, однако не смогли полностью изменить основы социальной структуры этносов. Долгие годы подчеркивание связей со своим родом воспринималось как «местечковость», но родовое деление, родовая идентичность не теряли своей значимости.

Декларируемой формой субэтнической дифференциации авторы называют события, мероприятия, наименования, публичные выступления и акции все то, что подчеркивается инициаторами и субъектами действий в качестве возрождаемой традиционности этнической культуры, когда родовое, родоплеменное деление признается необходимой частью традиционной культуры. Недекларируемые формы разворачиваются без постановки высоких целей, в сфере социальных, бытовых отношений, в том числе для решения групповых экономических $и$ политических задач.

Собственно социально-демографические, миграционные процессы в регионах не указывают на то, чтобы происходили физические расколы этносов, их распады и образования новых групп. Напротив, во многом, идет усиление урбанизации, отток населения из сел и многие внутриэтнические проблемы возникают в условиях концентрации в одном месте представителей разных родственных групп, которые до этого проживали относительно раздельно. Авторы полагают, что актуализация темы внутренней сложности этносов, групп в их составе идет в одном ряду с актуализацией в целом темы этничности в современных условиях.

Ключевые слова: российские этносы; субэтнические группы; субэтнические дифференциации; субэтническая идентичность; калмыки; тувинцы; Калмыкия; Тува; архаизация; клановость
In this article, the authors focus on sub-ethnic differentiations within the contemporary Kalmyk and Tuvan ethnicities.

A quickglance at the ethnogenesis ofboth Kalmyks and Tuvans explains the complex structure of these ethnicities. The social structures of both societies rested upon patrilineal clans, where all relatives of one's father comprise a settlement (hoton or aal). Kinship, clan identities, knowledge of your relatives and genealogy was extremely important. However, the internal structure of an ethnicity was more complex and did not limit itself to clans, especially among Kalmyks. The events of the 20th century have had contradictory impact on the ethnosocial processes, but definitely failed to fully transform the basic social structures of both ethnicities. For a number of decades, proud display of belonging to a kinship group has been seen as an element of 'parochial thinking', but the clan identity never lost its edge.

Declarative forms of sub-ethnic differentiations can be found in events, public attributions and talks, or indeed any other activity openly acknowledged by its subject as a form of revival of ethnic culture. In this context, clan groups are accepted as an integral part of traditional culture. Non-declarative forms, in contrast, reveal themselves without lofty goals. They are used in the field of everyday social and ethnic relations, especially when an economic or political issue has to be addressed by a group of interconnected individuals.

The sociodemographic and migration-related regional processes as such do not indicate any physical split within an ethnicity, which would have predicted its future collapse and the arrival of new entities. On the contrary, increasing urbanization, the out-migration from the countryside and other interethnic issues arise where various kinship groups which had been living separately now flock to the same area. The authors believe that accentuating the issue of ethnicities' internal complexity, as well as acknowledging the presents of composite kinship groups, will help actualize the role of ethnicity in contemporary society.

Keywords: ethnicities in Russia; sub-ethnic groups; sub-ethnic differentiations; sub-ethnic identity; Kalmyks; Tuvans; Kalmykia; Tuva; archaization; clan structure 


\section{Введение}

Одна из современных актуальных проблем национальной политики России упрочение общероссийского гражданского самосознания, что провозглашено одной из главных целей государственной национальной политики Российской Федерации, согласно принятой в 2012 г. Стратегии национальной политики РФ (Указ Президента ... 2012: Электр. ресурс). Это же направление научных исследований приоритетно для теоретических воззрений авторитетного ученого В. А. Тишкова (Тишков, 2003) и ряда других авторов. В этих условиях, а также после многократно обсужденной темы клановости, землячества, трайбализма в российской, региональной общественной жизни, что расцвели в 1990-е годы, тема не просто региональной идентичности, этнической идентичности, но субэтнической дифференциации - кажется не особенно популярной.

Однако, за последние годы в отечественном научном знании опубликовано достаточно статей, монографий, а также защищены диссертационные исследования по теме субэтнических групп, субэтнических идентичностей, прежде всего в российских регионах - так называемых национальных республиках. Авторы пишут о субэтносах бурят (Доржиева, 2005; Требугова, 2011), калмыков (Болдырева, 2009; Намруева, 2010; Бакаева, 2010), алтайцев (Чемчиева, 2012; Нечипоренко, 2014), абазин (Камбачокова, 2013) и др. Работы показывают интерес исследователей, преимущественно проживающих в данных регионах и включенных в ткань сложных социальных взаимоотношений в них, к проблематике внутриэтнического разнообразия, актуализации темы групп в составе этносов.

Мы попытаемся сформулировать проблемы и перспективы подобных исследований и в качестве материала приведем примеры из этносоциальной жизни калмыков и тувинцев.

\section{Вопрос о терминах}

Проблематика субэтнической дифференциации обсуждается в отечественной науке с 1980-х гг. и поднималась в трудах Ю. В. Бромлея (Бромлей, 1983), Р. Ф. Итса и др. Терминов, означающих составляющие этносов, достаточно: «этническая группа», «этнографическая группа», «малая группа», «этнолокальная группа», «субэтническая группа» и др. В конце XX в. изучение малых этнических групп актуализировалось. В связи с тем, что тема стала подниматься преимущественно представителями региональных научных центров, по понятным причинам термины с использованием слова «малый» («малая») стали менее востребованными. Чаще всего в работах теперь встречается понятие «субэтническая группа», но без существенных разъяснений его использования. А, надо подчеркнуть, за термином так и не закрепилась единая трактовка. 
Как показывает даже краткий обзор имеющихся определений, начиная с Ю.В.Бромлея, мнения относительно субэтнических групп существенно различались и продолжались различаться (Логинов, 2009: 58-59). Например, к субэтническим группам Ю. В. Бромлей предложил относить «отмеченные специфическими чертами культуры совокупности людей внутри этносов, которые обладают самоназванием» (Бромлей, 1983: 85). В формулировке В. К. Козлова субэтническая группа это «общность людей, составляющая часть этноса, занимающая компактную территорию и обладающая в силу этого культурной и языковой спецификой и элементами общего самосознания этнического» (Козлов, 1994: 461). При этом, автор указывает на определенный эволюционный этап развития этноса, с которого можно говорить об образовании субэтнических групп. По его мнению, происходит это вследствие неполной консолидации этноса или в результате сепарации, например, при миграции части этноса (там же). Остаточным явлением субэтнических групп В. В. Козлов называет этнографические группы, хотя в дальнейшем они могут снова превратиться в субэтническую группу (там же: 466).

Современныеавторычастонезадаютсянеобходимостьючеткогоопределения используемого термина, теоретического обоснования, концентрируясь на полевых материалах, анализируя социальную жизнь конкретных этносов и их составных групп. В итоге субэтническая группа в этих публикациях выступает то группой с набором признаков, включая субэтническое самосознание, групповое народное наречие, групповое самосознание и компактную территорию проживания (Логинов, 2009: 59), то родоплеменной группой (Трегубова, 2011: 4), то этнической группой, признанной коренным малочисленным на-родом (Чемчиева, 2012: 5). Очевидно, что речь идет о разных предметах и даже объектах исследований.

Попытка внести терминологическую ясность в исследования, посвященные внутриэтническим различиям и сложностям взаимоотношений, и выяснения того, какой объект может и должен называться «субэтнической группой», а какой - нет, может, на наш взгляд, увести нас далеко от собственно конкретных этносоциальных проблем. В этом плане более продуктивной представляется главное: признание этносов в целом как сложных образований с внутренней структурой (мезоструктурой), о чем писал А. А. Сусоколов, в состав которой входят родственные группы, устойчивые территориальные общности, некоторые профессиональные категории и т. д. (Арутюнян, Дробижева, Сусоколов, 1998: 216-217). В них на уровне межличностного общения формируются и передаются наиболее устойчивые нормы поведения, социально-психологические особенности народа, воспитывается этническое самосознание. Этносоциолог подчеркнул, что разрушение мезоструктуры очень осложняет, а порой делает невозможным воспроизводство этнической традиции и поддержание этнической идентификации (там же; см. также: Намруева, 2012а). И чтобы не уг- 
лубляться в споры относительно состава этой мезоструктуры, классификации ее составных элементов, критериям выделения таксономических единиц (хотя, безусловно, это важная тема), мы бы предложили для обсуждения вопросов разделения этнических явлений, в том числе групп этнических идентичностей, использовать общий термин «субэтнические дифференциации», подразумевая под ним разные разделительные, различительные процессы, явления в этносоциальной жизни, которые имеют в своей основе сложносоставной характер мезоструктуры этносов, выражают групповые формы этнической (субэтнической) идентичности, но которые не подразумевают собственно процессы субэтнизации как разделения, раскола этноса, появления новых субэтнических групп. По сути именно проблемы субэтнической дифференциации в российских регионах в том или ином плане поднимаются в исследованиях вышеназванных авторов, и обсуждаются они, прежде всего в плане переосмысления, самоутверждения этнической идентичностей на фоне новых социальных условий, в которых находится Россия в XXI веке, во втором его десятилетии.

Рассмотрим примеры субэтнических дифференциаций в республиках Калмыкии и Туве, коренное население которых - калмыки и тувинцы имеет родоплеменную структуру тюрко- и монголоязычных этнических групп. Поэтому они имеют много общего как между собой, так и с этносами, о «субэтнических группах» которых авторы стали писать. С 1990-х гг. в этих регионах, как и по всей России, процессы архаизации социокультурной жизни выразились в том числе в актуализации, усилении архаических родоплеменных связей, отношений, идентичностей (Ламажаа, 2011, 2013). При этом можно говорить о разных формах проявления субэтнических дифференциаций. Назовем их условно - декларируемыми и недекларируемыми.

Однако, прежде несколько слов о том, с какой сложившейся мезоструктурой рассматриваемые народы подошли к концу XX века.

\section{Мезоструктуры этносов калмыков и тувинцев до ХХ века}

В целом калмыки сохранили свой основной этнический состав улусов, с которым их предки-ойраты вышли из Джунгарии в начале XVII в. Подавляющее большинство калмыцких этнических подразделений (от крупных до мелких) имеют ойратское происхождение (Балинова, 2010: 13-14). Этнос сложился из ойратских групп торгутов, дербетов, хошутов, зюнгаров и хойтов, которые переселялись на Волгу в течение XVII и первой половины XVIII вв. и заняли в итоге степные пространства между Яиком и Волгой. Этническое ядро калмыцкого этноса в XVIII в. составили три основных компонента - торгуты, дербеты и хошуты. Названные подразделения калмыков распадались на различные по численности, происхождению и этническому составу улусные 
общности, которые в свою очередь делились на аймаки, а те в свою очередь в этническом плане разделялись на более мелкие группы: арбаны (десятки), торели и ясуны, которые чаще всего образуют население калмыцкого хотона.

Наследственное право калмыцких феодалов, закрепленное законами 1640 г. (Ики Цааджин бичик) и законами хана Дондук-даши, способствовало укреплению и сохранению этнических подразделений калмыков - улусов, оттоков и аймаков, вплоть до конца XVIII в. в составе так называемого Калмыцкого ханства. Кочевой образ жизни также косвенно закреплял разделение калмыцкого общества на улусы, оттоки и аймаки, хотя в них происходили эволюционные и качественные изменения. После ухода большой части калмыков в 1771 г. в Китай и последующей за ним ликвидации ханства в этническом составе калмыцкого народа произошли коренные преобразования (Эрдниев, 1980: 67). Этнический состав всех оставшихся - европейских калмыцких улусов оказался весьма сложным и разнородным, причем настолько, что каждый улус и тем более аймак стал включать в себя различные этнические, социальные и иные компоненты, закрепленные и оформленные за ним исторически под одним общим этническим наименованием (Балинова, 2010: 14). С. К. Хойт, проведя огромную сравнительную исследовательскую работу, писал, что современные калмыки сохраняют память о своей улусной, этнотерриториальной принадлежности, которую некоторые исследователи по ошибке называют племенной (Хойт, 2007). Э.П.Бакаева отмечает, что в советский период в калмыковедении проблемы исследования культуры народа на уровне субэтносов практически не затрагивались по ряду причин. Методологический подход к подобному делению отражен в обобщающем труде «Очерки истории Калмыцкой АССР»: «Родоплеменное деление ойратов и тем более калмыков в своей древней форме и древнем значении было давно пройденным этапом. Место родов и племен столетия тому назад заняли ойратская, затем - калмыцкая народности, поглотившие и растворившие в себе эти архаические группировки» (цит. по: Бакаева, 2010: 54).

Тувинский этнос также сохранил элементы сложного состава. Временем сложения первоначальных основ социально-этнической общности тувинцев М. Х. Маннай-оол считает VI-XII вв. (Маннай-оол, 2004: 119), а собственно же этнос с самоназванием «тувинцы» на территории Тувы сформировался в XVII в., главным образом в XVIII - первой половине XIX в. (там же: 129). Тува неоднократно завоевывалась, входила в состав различных ханств, общество подвергалось различным воздействиям, но в целом его деление продолжало строиться по родоплеменному принципу. И тувинцы проживали, точнее кочевали в пределах родовых территорий - кочевий, границы которых определялись по природным маркерам. Основы новой самоидентификации тувинцев, дальнейшей социальной дифференциации, были сформулированы в результате политики государства-завоевателя - Маньчжурской империи. 
Китайцами в Туве были образованы шесть больших хошунов (основных административных единиц Маньчжурской империи в Монголии и Туве) и несколько управляемых отдельно сумонов. Наибольшим из первых шести хошунов Тувы был Кемчикский (Хемчикский) хошун, занимавший территорию от р. Элегест до хребтов Сайлюгем, состоял он из 27 сумонов. Тесенгольский (или Оюннарский) хошун располагался на восток от р. Элегест по обоим склонам Танну-ола. Третий - Салчакский (Хемгольский) - хошун занимал юго-восток Тувы, четвертый - Тоджинский (или Тоджи-норский) - северовосток Тувы. Точных границ между сумонами и хошунами не было. Население, число которых было неравномерным, кочевало смешанно (Прокофьева, 2011: 55). В дальнейшем составы хошунов несколько менялись. В целом, как пишут 3. В. Анайбан и М. Х. Маннай-оол, установление административного деления, основанного главным образом не на родовом, а на территориальном принципе, способствовало стиранию племенных различий. Общее этническое самоназвание тувинцев «тыва-кижи» окончательно сложилось к началу XIX в. (Анайбан, Маннай-оол, 2013: Электр. ресурс). Лишь, особую группу в составе тувинцев - восточных тувинцев-тоджинцев этнографы, в частности С. И. Вайнштейн, назвали субэтнической (Вайнштейн, 1961). Особыми субэтническими группами тувинцев можно назвать тувинцев Монголии и Китая (внутренней Монголии), сведения о которых известны с XVIII в. М. В. Монгуш предлагает их считать скорее этнической группой (Монгуш, 2010: 10).

В целом, как пишут исследователи, основой социальной структуры общества калмыков и тувинцев был род, который считался по отцовской линии. Вся родня (по отцовской линии) составляла одно поселение (хотон или аал), который назывался по имени главного человека в роду. Родовым связям, родовой идентификации, знанию своего рода придавалось огромное значение (Ользеева, 2007; Монгуш, 2005). Тем не менее, внутренняя структура этноса была сложнее и включала не только роды, особенно у калмыков. На традиционный вопрос незнакомых калмыков «кенәхнә та?», который дословно означает «Кто вы?», «Чьих будете?» следуют примерно такие ответы: «Би баһа дөрвөд, абганар әәмгә, нойнакин әңгә, арван батькасуд, ясун хара ногай» («Я малый дэрбэт, из аймага абганер, анги (подразделения, отдела) нойнакин, десятка батькасуд, кости черный ногай»). По мнению Г. О. Авляева, эта многоступенчатость самосознания отражает административно-территориальную и этническую систему, обусловленную историческим прошлым европейских ойрат. Он писал, что улусно-аймачная административная система калмыков не являлась родоплеменной системой, а наименования отдельных звеньев этой системы (улус, отог, аймаг, анги, арван, ясун) не выражают собой понятия род, племя или родовое подразделение. Из чего следует, что в целом этническая терминология калмыцкого общества XVII-XVIII вв. имела больше административное происхождение, нежели родовое или племенное (Авляев, 2002: 50). 
Для тувинских групп в поздний маньчжурский период (вторая половина XIX - начало XX в.) исследователи предпочитали употреблять термины «родоплеменная группа» или «племя». Наиболее распространенными родо-племенными названиями у тувинцев назывались: иргит, кужугет, кыргыз, маады, монгуш, ондар, ооржак, салчак, сарыг, сат, соян, тонгак, тумат, тюлюш, уйгур, хертек, ховалыг, хомушку, чооду и др. Многие из этих названий сохранились и ныне в фамилиях тувинцев. Со второй половины $\mathrm{XX}$ в. стало очевидно, что родоплеменные идентичности стали уступать административным, территориальным. В целом тувинцы условно делятся на западных, южных и восточных, причем последние считаются собственно субэтнической группой - тувинцы-тоджинцы (они также вошли в состав коренных малочисленных народов Севера). Эта дифференциация также отмечается и в диалектах тувинского языка. Согласно Ш. Ч. Сат, имеется четыре диалекта: центральный (Дзун-Хемчикский, Сут-Хольский, Овюрский, УлугХемский, Пий-Хемский, северо-западная часть Тандинского района), западный (Бай-Тайгинский, Монгун-Тайгинский, Барун-Хемчикский), юго-восточный (Тандинский от Элегеста, Межегея, далее Тес-Хемский, Эрзинский районы), северо-восточный, т. е. тоджинский с таежным и речным говорами. Кроме того, согласно этой классификации, существует два переходных говора: каахемский и терехольский (Сат, 1987: 24-25).

Анализируя современное расселение калмыков в республике, можно условно выделить территориальные зоны дербетов, торгутов, а также смешанного проживания дербетов (больших дербетов) и бузавов. Торгуты, как и прежде, проживают компактно на востоке и юго-востоке республики (четыре сельских района, г. Лагань), дербеты - на севере и в центре (семь сельских районов). Бузавы несколько преобладают среди калмыцкого населения на западе (два сельских района, г. Городовиковск). Современные хошуты, численность которых мала, локализованы в республике в двух сельских населенных пунктах. В столице республики Калмыкия, городе Элисте, бузавы, дербеты и торгуты представлены примерно равными по величине группами. 3. Гоголданова отмечает, что Элиста выступает в качестве своеобразного республиканского этногруппового «котла», вследствие этого этнические процессы в Элисте носят более динамичный характер, чем в районах республики (Гоголданова, 1994: 20). Диалектная система калмыцкого языка имеет в своем составе, как установили лингвисты, три территориальных говора - торгутский, дербетский, бузавский (Убушаев, 2011: 5). Разница между ними в целом невелика, в основном касается фонетики, хотя есть и лексические особенности. Дербетский говор распространен в северных районах республики, торгутский - в восточных, бузавы жили на Дону, затем в западных районах республики. При выделении говоров учитывается не только языковой ландшафт, но и специфические черты культуры, самосознание (Омакаева, 2010: 380). 
Исторические события XX века по-разному повлияли на этносоциальные процессы у калмыков и тувинцев, однако не смогли полностью изменить основы социальной структуры этносов. Сталинская насильственная депортация калмыков (1943-1956 гг.) оставила свои горькие следы: многие родовые хотоны были уничтожены и вновь не восстановлены. Для тувинцев значимым фактором в первую очередь стала кампания по оседлости и коллективизации, развернутая в конце 1940 - начале 1950-х годов в продолжение курса на социализм, который был взят в Туве (еще будучи в качестве отдельного государства - Тувинской народной республике) в 1929 г. (Ламажаа, 2010а: 68-75). Тогда кочевые аратские хозяйства объединялись, тувинцы переводились на оседлость, было провозглашено создание советских тувинцев.

Долгие годы подчеркивание связей со своим родом воспринималось как «родовизм», «улусизм», «местячковость», «узколобый патриотизм». Подобные проявления пресекались партийными органами, за них могли снять с работы, и даже сажать в тюрьмы. Но, как подчеркивает М. В. Монгуш, родовое деление, родовая идентичность не теряли своей значимости, их роль в социальном контексте всегда оставалась существенной: по родам формировалось селение, каждый род в прошлом имел свое знамя, буддийский храм, оваа (Монгуш, 2010: 165-166).В начале 2000-х гг. В.С.Донгак в социологическом исследовании определила, что внутриродовые связи существенно влияют на самоидентификацию почти половины современных тувинцев - 46,2\% (Донгак, 2003: 14).

\section{Субэтнические дифференциации декларируемые}

В 1990-е гг. общий процесс национального возрождения в российских регионах выразился в широком обсуждении темы возрождения народных традиций, проведении мероприятий разного уровня, восстановлениях родовых идентичностей, практике усиления родоплеменных связей в разных формах.

Декларируемой формой субэтнической дифференциации мы назовем события, мероприятия, наименования, публичные выступления и акции - все то, что подчеркивается инициаторами и субъектами действий в качестве возрождаемой традиционности этнической культуры, когда родовое, родоплеменное деление признается необходимой частью традиционной культуры. Среди подобных явлений утверждение правила: каждый человек обязан знать своих предков, свою генеалогию, свой род до определенного колена. В Калмыкии исследование в форме анкетного опроса 283 чел. (калмыков) в 2010 г., проведенного отделом социально-политических и исследований КИГИ РАН с участием одного из соавторов статьи, позволил определить определенную степень интереса к своему прошлому среди представителей титульного населения. Например, при ответе на вопрос «Имеется ли у вас 
интерес к своей родословной?», выяснилось, что только десятая часть (10,5\%) опрашиваемых не интересуется историей своего рода. Большинство же (78\%) респондентов в разной степени проявляют интерес к родословной. Причем при выяснении формы проявления интереса, обнаружилось, что $22 \%$ респондентов составили свое генеалогическое дерево, 33\% собирают сведения о своих предках (Намруева, 2015а: 79).

Современные калмыки стремятся возродить память о земле предков, посещая малую родину, возводя там культовые сооружения, субурганы (буддийские ступы). Представители различных родов регулярно устраивают в степи большой молебен - газран тяклгн (освящение земли). Так, каждый калмыцкий род стремится возвести ова - обитель родовых духов. На этом священном месте проводятся различные религиозные ритуалы, посвященные хранителям рода, местности, духам воды, земли, воды, пространства. Один из авторов статьи присутствовал на заключительном этапе строительства одного из таких ова. В строительстве священного ова принимали участие представители всех восьми арванов Бага-Чоносовского рода. При этом приглашенные ламы читали молитвы на калмыцком языке во имя мира, добра и благоденствия багачоносовцев. Принято считать, что с возведением ова хранители рода успокоились и обрели долгожданный покой, а у соплеменников появилась возможность выполнять все религиозные ритуалы на малой родине (Шакуев, 2015).

Весьма распространенными сборы представителей родов - у родовых мест, с приглашением шаманов, восстановление и освящение родовых храмов и культовых объектов (оваa) стали и в Туве.Другому соавтору статьи приходилось присутствовать на таких сборах: семьи собираются всех поколений и старшие особенно уповают на то, чтобы молодежь, дети знали многочисленных родственников, могли с ними общаться, а также понимали, откуда они родом, кто их предки. Здесь молятся за сохранность земли, рода, за благополучие каждого из его членов. Средства и силами членов одной кровно-родственной группы строятся буддийские храмы (хурэ) и буддийские ступы (Монгуш, 2010: 167). Тема знания родовых корней развивается местными учеными при поддержке властей. Тувинским государственным университетом в 2010-2011 гг. проводился республиканский конкурс «Древо рода: откуда я? Кто там?» Некоторые из его участников посчитали свою родословную до 13 колена. Хотя по материалам конкурсных работ предполагается решение прежде всего генетических задач, в том числе создание банка генетических данных (поскольку работы ведутся лабораторией генетики), это включает и анализ родословных населения региона, учет внутреннего многообразия тувинского этноса.

Субэтническиедифференциации подчеркиваются в наименованиях, заметны по вывескам, названиям. Калмыки стали называть свои поселки, предприятия, магазины по имени своего рода: «Ики чонос» («Большие волки»), «Ики бухус» 
(«Большие быки»), «Харнут» («Чернявые»); появились книги, посвященные истории малой Родины: «Эркетени», «Станица Граббевская», «Хотон Эндыр» (Гучинова, 2003: 22).

У калмыков и тувинцев популярными стали краеведческие исследования школьников по истории малой Родины, издаются книги по краеведению, по истории своего рода (Намруева, 2012b: 78). В системе образования республик созданы условия для наилучшего восприятия элементов этнической культуры, формирования этнического самосознания у молодого поколения. На это нацелены образовательные программы «Основы буддизма», «История и культура родного края», «Тодо бичиг» (старокалмыцкая письменность), «История Тувы» и др., которые преподаются в школах регионов с середины 1990-х гг. Разнообразные конкурсы и фестивали - «Цаган ботхн» («Белый верблюжонок»), «Танцевальная весна», фольклорно-этнографический фестиваль «Джангрин ачнр» («Внуки Джангара»), конференция «Бичкн төрскн» («Малая родина») и др. в Калмыкии; праздники Шагаа, Наадым, фестиваль живой музыки и веры «Устуу-Хурээ» и др. в Туве - направлены на передачу подрастающему поколению республики уважения к языку и культуре, знания традиций, опыта жизни этноса.

Так, декларируемые проявления субэтнических дифференциаций носят характер публичный и свидетельствуют об актуализации родоплеменной субэтнической идентичности.

\section{Субэтнические дифференциации недекларируемые}

Если декларируемые формы субэтнических дифференциаций, как мы сформулировали, ставит задачи восстановления традиций, то недекларируемые формы разворачиваются без постановки высоких целей, в сфере социальных, бытовых отношений, в том числе для решения групповых экономических и политических задач.

В условиях социальной аномии и анархии по всей России с начала 1990-х годов население ухватилось за старые, архаические формы взаимоотношений, а том числе в Калмыкии и Туве - за те, которые когда-то составляли основу кочевого общества. Когда окружающий мир стал восприниматься опасным, враждебным, представления о тех, кого можно считать своими, конкретизировались в первую очередь до расширенной семьи - рода. Возобладала тактика семейного коллективного выживания, увеличение доли сложных семей, даже в городских поселениях (см. об архаизации: Ламажаа, 2013: 192-200).

Востребованными оказались традиционные нормы и представления, связанные с родовой взаимопомощью. Сложности переходного периода, резкое снижение общего жизненного уровня, безденежье, длившееся годами из-за 
невыплат заработной платы, обязывало людей, состоящих даже в дальнем родстве, помогать друг другу, делиться тем, что имеешь, со всеми поровну. В этом проявлялось не столько коллективное начало, сколько чувство принадлежности к общине (Монгуш, 2010: 167).

Субэтнические дифференциации стали активно проявляться и в деловой сфере. Первые частные предприятия в Туве основывались по признаку родства, клановости, что далеко не всегда было в плюс самому бизнесу, поскольку главным кадровым принципом была не квалификация, а родственная связь, и надежды при этом возлагались в первую очередь на преданность и надежность принятого родственника (там же: 168). Подобные явления наблюдаются и в Калмыкии. Конечный результат предприятий, основанных по родственно-земляческому признаку, не всегда бывает положительным. Всетаки современные деловые отношения требуют профессионализма, наличия коммуникативных качеств, ответственности, инициативности. Отсутствие их не спасет никакая близкородственная связь.

Политическая сфера республик стала одной из главных арен для разворачивания субэтнической дифференциации, особенно на рубеже XX-XXI веков. И там, и там расцвели клановые структуры во власти. Принципы кадровой политики, продолжающиеся базироваться на принципах работы партийной номенклатуры, существенно дополнились и архаическими социальными сетями (Ламажаa, 2010b; Улинова, 2011). Усиление родоплеменных начал распространилось как в «низах» общества, так и в «верхах». Сплочение у руля власти большой семейно-родоплеменной и районной группы, привлекшей на свою сторону своих сторонников на основании личной зависимости, означало реанимацию древней традиции кочевой культуры - клановости во власти.

В обыденном сознании тувинцев и калмыков существование групп внутри этноса признается, как признаются сложные взаимоотношения между представителями разных групп. Тувинский народный фольклор содержит в себе немало песен и частушек, в которых в шуточной или бранной форме дается характеристика тому или иному роду. Эта характеристика подчас бывает нелицеприятной, иногда напоминает «дразнилку», но может быть и совершенно безобидной. Цель ее не только противопоставить один род другому, но и подчеркнуть наиболее характерную черту конкретного рода (Монгуш, 2010: 166). Например, собиратель тувинского фольклора Г. Н. Курбатский вычленил сквозь фольклорные формы тему межродовых характеристик и перечислил: донгаки считаются чрезмерно гордыми, монгуши - независимыми и кичливыми, ондары - грубыми и колкими, саая - жадными и ненасытными, хертеки - невезучими, ховалыги - клеветниками, хомушку - сплетниками, салчаки - черствыми. Передаваясь из уст в уста, эти характеристики часто становились устойчивыми стереотипами, отличающими один род от другого (Курбатский, 2001: 193-194). В постсоветское время эти стереотипы вновь 
вышли из фольклорных кладовых в сферу общения. Также тувинцы получили возможность идентифицировать себя по административному признаку (часто противопоставляя себя другим группам): тес-хемские, улуг-хемские, пий-хемские, барун-хемчикские, дзун-хемчикские, монгун-тайгинские, сутхольлские, эрзинские, тоджинские и др.

Подобное деление, групповая самоидентификация и идентификация воспринимается не столь однозначно в сообществах. Например, что показал опрос населения 2010 г. в Калмыкии. Спектр ответов в анкете на закрытый вопрос «Как вы относитесь к делению калмыков на субэтнические группы?» был разнообразен. Так, почти половина опрошенных $(48,8 \%)$ это деление воспринимает положительно, из них 16,6\% респондентов отмечают то, что оно позволяет сохранить культуру, народ, а почти треть всех респондентов (32,2\%) указывают на то, что субэтнические группы имеют древнюю историю, которую надо сохранять. Об отрицательном отношении к делению калмыков заявили $22,9 \%$ анкетируемых. Почти четверть опрашиваемых $(23,7 \%)$ к этому явлению относится по-разному, в зависимости от ситуации (Намруева, 2015b: 161).

В Туве подобный опрос не проводился, однако по нашим наблюдениям, тема обособленности, противопоставления родоплеменных групп тоже стала очевидной, широко обсуждаемой в обществе, в СМИ - в самых разных тональностях, хотя и не любимой властью. В том числе, например, в общественном дискурсе стали обсуждать родоплеменную принадлежность руководителей республики в течение всего XX века и делать заключения о том, что возвышение одного человека является с одной стороны следствием усиления позиций его кожууна, а с другой стороны - влечет за собой укрепление позиций территории и духа его населения. Подобные обсуждения имеют как сторонников, так и противников данной дифференциации, причем чаще всего в зависимости от того, к какому «лагерю» примыкает участник дискуссии: к лагерю «выигравшей» группы, к лагерю «проигравшей», или вовсе не к той и не другой, если это представитель иной национальности.

\section{Заключение}

Краткий обзор материала современных проявлений субэтнических дифференциаций калмыков и тувинцев, а также учет публикаций по субэтническим группам в других российских регионах ставит перед исследователями теоретические вопросы. Есть ли необходимость говорить о появлении новых групп в составе региональных этносов, о современной субэтнизации, каком-то новом витке этногенеза в данных регионах? Мы полагаем, что нет. Собственно социально-демографические, миграционные процессы в регионах не указывают на то, чтобы происходили физические расколы этносов, их распады и 
образования новых групп. Напротив, во многом, идет усиление урбанизации, отток населения из сел и многие внутри-этнические проблемы возникают в условиях концентрации в одном месте представителей разных родственных групп, которые до этого проживали относительно раздельно. Вопрос об особых правах также возникает чаще как результат неудовлетворенности социальноэкономическими условиями проживания. Соперничество обостряется в политической сфере по поводу сфер влияния в целом на региональный социум и за ресурсы субъекта федерации.

В целом, мы полагаем, что актуализация темы внутренней сложности этносов, групп в их составе идет в одном ряду с актуализацией в целом темы этничности в современных условиях.

\section{СПИСОК ЛИТЕРАТУРЫ}

Авляев, Г. О. (2002) Происхождение калмыцкого народа. 2-е изд., перераб. и исправл. Элиста : Калм. кн. изд-во. 325 с.

Анайбан, 3. В., Маннай-оол, М. Х. (2013) Происхождение тувинцев. История вопроса [Электронный ресурс] // Новые исследования Тувы. № 3. URL: https:// nit.tuva.asia/nit/article/view/220 (дата обращения: 12.08.2016).

Арутюнян, Ю. В., Дробижева, Л. М., Сусоколов, А. А. (1998) Этносоциология. М. : Аспект-пресс. 271 с.

Бакаева, Э. П. (2010) «Чьи вы?» (специфика полевой работы в среде калмыков в связи с проблемой самоидентификации) // Этнографическое обозрение. № 3 . C. 54-65.

Балинова, Н. В. (2010) Калмыки: антропогенетический портрет. Элиста : ЗАОр «НПП «Джангар». 144 с.

Болдырева, В. М. (2009) Эркетеневские калмыки: субэтнические особенности культуры (на материале ритуала жертвоприношения огню) // Известия Алтайского государственного университета. № 4-2. С. 22-27.

Бромлей, Ю. В. (1983) Очерки теории этноса. М. : Наука. 412 с.

Вайнштейн, С. И. (1961) Тувинцы-тоджинцы. Историко-этнографические очерки. М. : Наука. 218 с.

Гоголданова, З. Э.-Г. (1994) Субэтносы и этнические процессы в Калмыкии в середине 80-х годов XX столетия (по материалам статистико-этнологического обследования) : автореф. дис. ... канд. ист. наук. М. 24 с.

Григорьян, К. Э. (2002) Субэтнические группы армян : дисс.... к. ист. н. М. 187 с.

Гучинова, Э.-Б. М. (2003) Постсоветская Элиста: власть, бизнес и красота: Очерки социально-культурной антропологии калмыков. СПб.: Алетейя. 180 с. 
Донгак, В. С. (2003) Этническая идентичность тувинцев : автореф. дисс.... к. с. н. СПб. 25 с.

Доржиева, Д. А. (2005) Субэтносы в процессе этнической консолидации бурят : автореф. дисс. ... к. ист. н. Улан-Удэ. 22 с.

Камбачокова, М. Ю. (2013) К вопросу об основных этапах становления этноса и субэтническом составе абазин // Известия Кабардино-Балкарского государственного университета. Т. III. № 1. С. 45-48.

Козлов, В. И. (1994) Этническая группа // Народы России: Энциклопедия / гл. ред. В. А. Тишков. М. : Большая Российская энциклопедия. 479 с. С. 466.

Курбатский, Г. Н. (2001) Тувинцы в своем фольклоре (историко-этнографические аспекты тувинского фольклора). Кызыл: Тувинское книжное издательство. 464 с.

Ламажаa, Ч. К. (2010а) Тува между прошлым и будущим. 2-е изд. СПб. : Алетейя. 368 с.

Ламажаa, Ч. К. (2010b) Клановость в политике регионов России. Тувинские правители. СПб. : Алетейя. 208 с.

Ламажаа, Ч. К. (2011) Воспроизводство архаики. Почему? // Человек. № 2. C. 97-103.

Ламажаa, Ч. К. (2013) Архаизация общества. Тувинский феномен. М. : Книжный дом «Либроком». 272 с.

Логинов, К. К. (2009) Названия и самоназвания субэтнических групп и феномен «субэтнической мимикрии» в Карелии и на некоторых сопредельных территориях // Вестник Санкт-Петербургского университета. Сер. 2. Вып. 4. С. 59-62.

Маннай-оол М. Х. (2004) Тувинцы : происхождение и формирование тувинского этноса. Новосибирск : Наука. 166 с.

Монгуш, М. В. (2005) Тувинцы России, Монголии и Китая: этнические и этнокультурные процессы, современная идентичность : автореф. дисс. ... д-ра ист. н. М. 52 с.

Монгуш, М. В. (2010) Один народ: три судьбы. Тувинцы России, Монголии и Китая в сравнительном контексте. Осака : Национальный музей этнологии. 358 с.

Намруева, Л. В. (2012а) Роль мезоструктуры в сохранении этничности (на примере калмыков) // Актуальные вопросы и достижения современной антропологии : сб. научн. тр. Новосибирск: Изд-во ООО «Сибпринт». 377 с. C. 78-86.

Намруева, Л. В. (2012b) Молодежь и процессы возрождения этнической культуры в Калмыкии» // Вестник Калмыцкого института гуманитарных исследований РАН. № 4. С. 76-80. 
Намруева, Л. В. (2015а) Субэтническая идентичность современных калмыков: социокультурный аспект // Известия высших учебных заведений. Coциология. Экономика. Политика. № 1. С. 120-125.

Намруева, Л. В. (2015b) Модели культурной социализации // Намруева Л. В. Этническая социализация молодежи Республики Калмыкия (анализ 2000-2010-х гг.) Элиста : Калмыцкий институт гуманитарных исследований PAH. 195 c. C. $156-173$.

Нечипоренко, О. В. (2014) Субэтносы Республики Алтай: особенности этнической и гражданской идентичности // Этносы и формирование гражданской нации: диалектика российской национальной политики Сборник материалов Всероссийской научно-практической конференции / науч. ред. И. В. Фролова. Уфа : БАГСУ. С. 259-263.

Ользеева, С. 3. (2007) Калмыцкие народные традиции (на калмыцком и русском языках). Элиста : ЗАОр «НПП «Джангар». 480 с.

Омакаева, Э. У. (2010) Калмыцкий язык: история и современность // Калмыки / отв. ред. Э. П. Бакаева, Н. Л. Жуковская. М. : Наука. 568 с. С. 375-382.

Прокофьева, Е. Д. (2011) Процесс национальной консолидации тувинцев. СПб. : Наука. 535 с.

Сат, Ш. Ч. (1987) Тыва диалектология [Тувинская диалектология] : учебное пособие. Кызыл : Тувинское книжное издательство. 99 с. (На тув. яз.).

Тишков, В. А. (2003) Реквием по этносу: исследования по социальнокультурной антропологии. М. : Наука. 544 с.

Трегубова, Д. Д. (2011) Субэтнические группы бурят в прошлом и настоящем : автореф. дисс. ... к. ист. н. М. 24 с.

Убушаев, Н. Н. (2011) Проблема сложения диалектной системы калмыцкого языка и ее функционирование : автореф.... д-ра филол. наук. М. 57 с.

Указ Президента Российской Федерации от 19.12.2012 г. № 1666 О Стратегии государственной национальной политики Российской Федерации на период до 2025 года (2012) [Электронный ресурс] // Президент России. URL: kremlin.ru/ acts/bank/36512 (дата обращения: 12.08.2016).

Улинова, И. Н. (2011) Этническое представительство в административной корпоративности и его роль в калмыцком обществе // Вестник ТГПУ. № 11 (114). C. 241-245.

Хойт, С. К. (2007) Вопросы этнической и административно-территориальной структуры ойратских групп // Проблемы этногенеза и этнической культуры тюрко-монгольских народов. Элиста: Изд-во КГУ. 180 с. С. 157-177.

Чемчиева, А. П. (2012) Алтайские субэтносы в поисках идентичности. Новосибирск : Изд-во ИАЭТ СО РАН. 254 с. 
Шакуев, В. (2015) Построена Бага-Чоносовская ова // Хальмг унн (газета). 20 октября. С. 2.

Эрдниев, У. Э. (1980) Калмыки. Элиста : Калм. книж. изд-во. 284 с.

Дата поступления: 18.04.2018 г.

\section{REFERENCES}

Avliaev, G. O. (2002) Proiskhozhdenie kalmytskogo naroda [The origin of the Kalmyk people]. 2nd ed. Elista, Kalm. kn. izd-vo. 325 p. (In Russ.).

Anayban, Z. V. and Mannai-ool, M. Kh. (2013) Proiskhozhdenie tuvintsev. Istoriia voprosa [The Genesis of Tuvans: Historical background]. The New Research of Tuva, no. 3 [online] Available at: https://nit.tuva.asia/nit/article/view/220 (access date: 12.08.2016). (In Russ.).

Arutiunian, Iu. V., Drobizheva, L. M. and Susokolov, A. A. (1998) Etnosotsiologiia [Ethnosociology]. Moscow, Aspekt-press. 271 p. (In Russ.).

Bakaeva, E. P. (2010) «Ch'i vy?» (spetsifika polevoi raboty v srede kalmykov v sviazi s problemoi samoidentifikatsii) ["Whose People Are You?": The Specifics of Fieldwork among the Kalmyk in Connection with the Issue of Self-Identification)]. Etnograficheskoe obozrenie, no. 3, pp. 54-65. (In Russ.).

Balinova, N. V. (2010) Kalmyki: antropogeneticheskii portret [The Kalmyks: An Anthropogenetic Portrait]. Elista, ZAOr «NPP «Dzhangar». 144 p. (In Russ.).

Boldyreva, V. M. (2009) Erketenevskie kalmyki: subetnicheskie osobennosti kul'tury (na materiale rituala zhertvoprinosheniia ogniu) [Erlenescar Kalmyks: subethnic features of culture: the case of fire sacrifices]. Izvestiia Altaiskogo gosudarstvennogo universiteta, no. 4-2, pp. 22-27. (In Russ.).

Bromlei, Iu. V. (1983) Ocherki teorii etnosa [Essays on the Theory of Ethnos]. Moscow, Nauka. 412 p. (In Russ.).

Vainshtein, S. I. (1961) Tuvintsy-todzhintsy. Istoriko-etnograficheskie ocherki [Tozhu tuvans: historical and ethnographic essays]. Moscow, Nauka. 218 p. (In Russ.).

Gogoldanova, Z. E.-G. (1994) Subetnosy $i$ etnicheskie protsessy $v$ Kalmykii v seredine 80-kh godov XX stoletiia (po materialam statistiko-etnologicheskogo obsledovaniia) [Sub-ethnicities and ethnic processes in Kalmykia in the mid-1980s (based on the statistical and ethnological survey)]: Thesis of Diss.... Candidate of History. Moscow. 24 p. (In Russ.).

Grigor'ian, K. E. (2002) Subetnicheskie gruppy armian [Sub-ethnic groups of Armenians] : Diss.... Candidate of History. Moscow. 187 p. (In Russ.). 
Guchinova, E.-B. M. (2003) Postsovetskaia Elista: vlast', biznes i krasota: Ocherki sotsial'no-kul'turnoi antropologii kalmykov [Post-Soviet Elista: power, business and beauty/ Essays on the socio-cultural anthropology of the Kalmyks]. St. Petersburg, Aleteiia. 180 p. (In Russ.).

Dongak, V. S. (2003) Etnicheskaia identichnost' tuvintsev [Ethnic identity of the Tuvans]: Thesis of Diss.... Candidate of Sociology. St. Petersburg. 25 p. (In Russ.).

Dorzhieva, D. A. (2005) Subetnosy v protsesse etnicheskoi konsolidatsii buriat [Subethnicities in the process of ethnic consolidation of Buryats]: Thesis of Diss. ... Candidate of History. Ulan-Ude. 22 p. (In Russ.).

Kambachokova, M. Iu. (2013) K voprosu ob osnovnykh etapakh stanovleniia etnosa i subetnicheskom sostave abazin [On the question of the main stages of ethnic development and sub-ethnic composition of the Abazins]. Izvestiia KabardinoBalkarskogo gosudarstvennogo universiteta, vol. III, no. 1, pp. 45-48. (In Russ.).

Kozlov, V. I. (1994) Etnicheskaia gruppa [Ethnic group]. In: Narody Rossii: Entsiklopediia [Peoples Of Russia: Encyclopedia] / ed.-in-chef V. A. Tishkov. Moscow, Bol'shaia Rossiiskaia entsiklopediia. 479 p. P. 466. (In Russ.).

Kurbatskii, G. N. (2001) Tuvintsy v svoem fol'klore (istoriko-etnograficheskie aspekty tuvinskogo fol'klora) [Tuvans in their folklore: Historical and ethnographic aspects of Tuvan folklore)]. Kyzyl, Tuvinskoe knizhnoe izdatel'stvo. 464 p. (In Russ.).

Lamazhaa, Ch. K. (2010a) Tuva mezhdu proshlym i budushchim [Tuva between the past and the future]. 2nd ed. St. Petersburg, Aleteiia. 368 p. (In Russ.).

Lamazhaa, Ch. K. (2010) Klanovost' v politike regionov Rossii. Tuvinskie praviteli [The clan politics of Russia's regions. The Leaders Of Tuva]. St. Petersburg, Aleteiia. 208 p. (In Russ.).

Lamazhaa, Ch. K. (2011) Vosproizvodstvo arkhaiki. Pochemu? [The Reproduction of Archaicness. Why?]. Chelovek, no. 2, pp. 97-103. (In Russ.).

Lamazhaa, Ch. K. (2013) Arkhaizatsiia obshchestva. Tuvinskii fenomen [Archaization of the society. Tuvan phenomenon]. Moscow, Knizhnyi dom «Librokom». 272 p. (In Russ.)

Loginov, K. K. (2009) Nazvaniia i samonazvaniia subetnicheskikh grupp i fenomen «subetnicheskoi mimikrii» v Karelii i na nekotorykh sopredel'nykh territoriiakh [Names and self-names of sub-ethnic groups, and the phenomenon of "sub-ethnic mimicry" in Karelia and some adjacent areas]. Vestnik Sankt-Peterburgskogo universiteta, issue 2, vol. 4, pp. 59-62. (In Russ.).

Mannai-ool M. Kh. (2004) Tuvintsy: proiskhozhdenie i formirovanie tuvinskogo etnosa [Tuvans: the origin and formation of the Tuvan ethnos]. Novosibirsk, Nauka. 166 p. (In Russ.). 
Mongush, M. V. (2005) Tuvintsy Rossii, Mongolii i Kitaia: etnicheskie i etnokul'turnye protsessy, sovremennaia identichnost' [Tuvans of Russia, Mongolia and China: ethnic and ethno-cultural processes, modern identity]: Thesis of Diss. ... Doctor of History. Moscow. 52 p. (In Russ.).

Mongush, M. V. (2010) Odin narod: tri sud'by. Tuvintsy Rossii, Mongolii i Kitaia $v$ sravnitel'nom kontekste [One people, three destinies. Tuvans of Russia, Mongolia and China in a comparative context]. Osaka, Natsional'nyi muzei etnologii. 358 p. (In Russ.).

Namrueva, L. V. (2012a) Rol' mezostruktury v sokhranenii etnichnosti (na primere kalmykov) [The role of mesostructure in the preservation of ethnicity: the example of Kalmyks]. In: Aktual'nye voprosy i dostizheniia sovremennoi antropologii [Topical issues and achievements of modern anthropology]: collection of proceedings. Novosibirsk, 000 «Sibprint» Publ. 377 p. Pp. 78-86. (In Russ.).

Namrueva, L. V. (2012b) Molodezh' i protsessy vozrozhdeniia etnicheskoi kul'tury v Kalmykii [Youth and Revival of Ethnic Culture in Kalmykia]. Vestnik Kalmytskogo instituta gumanitarnykh issledovanii RAN, no. 4, pp. 76-80. (In Russ.).

Namrueva, L. V. (2015a) Subetnicheskaia identichnost' sovremennykh kalmykov: sotsiokul'turnyi aspekt [Subethnic identity of today's Kalmyks: sociocultural aspect]. Izvestiia vysshikh uchebnykh zavedenii. Sotsiologiia. Ekonomika. Politika, no. 1, pp. 120-125. (In Russ.).

Namrueva, L. V. (2015b) Modeli kul'turnoi sotsializatsii [Models of cultural socialization]. In: Namrueva L. V. Etnicheskaia sotsializatsiia molodezhi Respubliki Kalmykiia (analiz 2000-2010-kh gg.) [Ethnic socialization of young people of the Republic of Kalmykia (analysis of 2000-2010))]. Elista, Kalmytskii institut gumanitarnykh issledovanii RAN. 195 p. Pp. 156-173. (In Russ.).

Nechiporenko, O. V. (2014) Subetnosy Respubliki Altai: osobennosti etnicheskoi i grazhdanskoi identichnosti [Sub-ethnicities of the Altai Republic: peculiarities of ethnic and civil identity]. In: Etnosy i formirovanie grazhdanskoi natsii: dialektika rossiiskoi natsional'noi politiki Sbornik materialov Vserossiiskoi nauchno-prakticheskoi konferentsii [Ethnicities and the formation of the civil nation: the dialectics of Russian national policy. Proceedings of the all-Russian scientific and practical conference] / ed. by I. V. Frolova. Ufa, BAGSU. Pp. 259-263. (In Russ.).

Ol'zeeva, S. Z. (2007) Kalmytskie narodnye traditsii (na kalmytskom i russkom iazykakh) [Kalmyk folk traditions (in Kalmyk and Russian)]. Elista, ZAOr «NPP «Dzhangar». 480 p. (In Russ.).

Omakaeva, E. U. (2010) Kalmytskii iazyk: istoriia i sovremennost' [Kalmyk language: history and modernity]. In: Kalmyki [Kalmyks] / ed. by E. P. Bakaeva and N. L. Zhukovskaia. Moscow, Nauka. 568 p. Pp. 375-382. (In Russ.). 
Prokof'eva, E. D. (2011) Protsess natsional'noi konsolidatsii tuvintsev [The process of national consolidation of the Tuvans]. St. Petersburg, Nauka. 535 p. (In Russ.).

Sat, Sh. Ch. (1987) Tyva dialektologiia [Tuvan dialectology] : a textbook. Kyzyl, Tuvinskoe knizhnoe izdatel'stvo. 99 p. (In Tuv.)

Tishkov, V. A. (2003) Rekviem po etnosu: issledovaniia po sotsial'no-kul'turnoi antropologii [Requiem for Ethnicity. Studies in Social and Cultural Anthropology]. Moscow, Nauka. 544 p. (In Russ.).

Tregubova, D. D. (2011) Subetnicheskie gruppy buriat v proshlom i nastoiashchem [Sub-ethnic groups of the Buryats in the past and present] : Thesis of Diss.... Candidate of History. Moscow. 24 p. (In Russ.).

Ubushaev, N. N. (2011) Problema slozheniia dialektnoi sistemy kalmytskogo iazyka i ee funktsionirovanie [The issue of composition of the dialect system of the Kalmyk language and its function] : Thesis of Diss.... Doctor of Philology. Moscow. 57 p. (In Russ.).

Ukaz Prezidenta Rossiiskoi Federatsii ot 19.12.2012 g. № 1666 O Strategii gosudarstvennoi natsional'noi politiki Rossiiskoi Federatsii na period do 2025 goda [Decree of the President of the Russian Federation of 19.12.2012 № 1666 on the Strategy of the state national policy of the Russian Federation for the period up to 2025] (2012). Prezident Rossii [online] Available at: kremlin.ru/acts/bank/36512 (access date: 12.08.2016). (In Russ.).

Ulinova, I. N. (2011) Etnicheskoe predstavitel'stvo v administrativnoi korporativnosti i ego rol' v kalmytskom obshchestve [Ethnic representation in administrative corporatism and its role in Kalmyk society]. Vestnik TGPU, no. 11 (114), pp. 241-245. (In Russ.).

Khoit, S. K. (2007) Voprosy etnicheskoi i administrativno-territorial'noi struktury oiratskikh grupp [Issues of ethnic and administrative-territorial structure of Oirat groups]. In: Problemy etnogeneza i etnicheskoi kul'tury tiurko-mongol'skikh narodov [Problems of ethnogenesis and ethnic culture of the Turkic-Mongolian peoples]. Elista, Izd-vo KGU. 180 p. Pp. 157-177. (In Russ.).

Chemchieva, A. P. (2012) Altaiskie subetnosy v poiskakh identichnosti [Altai SubEthnicities: In Search ofr Identity]. Novosibirsk, Izd-vo IAET SO RAN. 254 p. (In Russ.).

Shakuev, V. (2015) Postroena Baga-Chonosovskaia ova [The Baga-Chonosovskaia Ova Completed]. Khal'mg unn (newspaper), 20 October, p. 2. (In Russ.).

Erdniev, U. E. (1980) Kalmyki [The Kalmyks]. Elista, Kalm. knizh. izd-vo. 284 p. (In Russ.).

Submission date: 18.04.2018. 


\section{Для цитирования:}

Ламажаа Ч. К., Намруева Л. В. Субэтнические дифференциации российских этносов (на примере калмыков и тувинцев) [Электронный ресурс] // Новые исследования Тувы. 2018, № 2. URL: https://nit.tuva.asia/nit/article/view/778 (дата обращения: дд.мм.гг.). DOI: 10.25178/nit.2018.2.11

\section{For citation:}

Lamazhaa Ch. K. and Namruyeva L. V. Sub-ethnic differentiations of Russian ethnic groups: the case of Kalmyks and Tuvans. The New Research of Tuva, 2018, no. 2 [online] Available at: https://nit.tuva.asia/nit/article/view/778 (accessed: ). DOI: 10.25178/ nit.2018.2.11 